\title{
Supplemental irrigation potential and impact on downstream flow of Karkheh River basin in Iran
}

\author{
Behzad Hessari $^{1}$, Adriana Bruggeman ${ }^{2}$, Ali Mohammad Akhoond-Ali ${ }^{3}$, Theib Oweis ${ }^{4,5}$, and Fariborz Abbasi ${ }^{6}$ \\ ${ }^{1}$ Water Engineering Department, Urmia University, Urmia, Iran \\ ${ }^{2}$ Energy, Environment and Water Research Center, The Cyprus Institute, Nicosia, Cyprus \\ ${ }^{3}$ Water Science Engineering Faculty, Shahid Chamran University of Ahvaz, Iran \\ ${ }^{4}$ International Center for Agricultural Research in the Dry Areas, ICARDA, Amman, Jordan \\ ${ }^{5}$ Tottori University, Hamasaka, Tottori, Japan \\ ${ }^{6}$ Agriculture Engineering Research Institute, Agricultural Research and Extension Organization, Tehran, Iran
}

Correspondence to: Behzad Hessari (b_hessari@yahoo.com)

Received: 14 September 2012 - Published in Hydrol. Earth Syst. Sci. Discuss.: 6 December 2012

Revised: 30 January 2016 - Accepted: 3 April 2016 - Published: 12 May 2016

\begin{abstract}
Supplemental irrigation of rainfed winter crops improves and stabilises crop yield and water productivity. Although yield increases by supplemental irrigation are well established at the field level, its potential extent and impact on water resources at the basin level are less researched. This work presents a Geographic Information Systems (GIS)based methodology for identifying areas that are potentially suitable for supplemental irrigation and a computer routine for allocating streamflow for supplemental irrigation in different sub-basins. A case study is presented for the $42908 \mathrm{~km}^{2}$ upper Karkheh River basin (KRB) in Iran, which has $15840 \mathrm{~km}^{2}$ of rainfed crop areas. Rainfed crop areas within $1 \mathrm{~km}$ from the streams, with slope classes $0-5,0-8,0$ 12 , and $0-20 \%$, were assumed to be suitable for supplemental irrigation. Four streamflow conditions (normal, normal with environmental flow requirements, drought and drought with environmental flow) were considered for the allocation of water resources. Thirty-seven percent $\left(5801 \mathrm{~km}^{2}\right)$ of the rainfed croplands had slopes less than $5 \% ; 61 \%\left(3559 \mathrm{~km}^{2}\right)$ of this land was suitable for supplemental irrigation, but only $22 \%\left(1278 \mathrm{~km}^{2}\right)$ could be served with irrigation in both autumn $(75 \mathrm{~mm})$ and spring $(100 \mathrm{~mm})$, under normal flow conditions. If irrigation would be allocated to all suitable land with slopes up to $20 \%, 2057 \mathrm{~km}^{2}$ could be irrigated. This would reduce the average annual outflow of the upper KRB by $9 \%$. If environmental flow requirements are considered, a maximum (0-20\% slopes) of $1444 \mathrm{~km}^{2}$ could receive supplemental irrigation. Under drought conditions a maximum
\end{abstract}

of $1013 \mathrm{~km}^{2}$ could be irrigated, while the outflow would again be reduced by $9 \%$. Thus, the withdrawal of streamflow for supplemental irrigation has relatively little effect on the outflow of the upper KRB. However, if the main policy goal would be to improve rainfed areas throughout the upper $\mathrm{KRB}$, options for storing surface water need to be developed.

\section{Introduction}

To achieve the world's growing needs for food, a better allocation of water resources for irrigation is needed. Supplemental irrigation is the application of a limited amount of water to essentially rainfed crops during dry spells to alleviate moisture stress, thus improving and stabilising yields (Oweis and Hachum, 2006). Supplemental irrigation is recommended for field crops in areas with an annual rainfall range of $300-600 \mathrm{~mm}$. The goal of supplemental irrigation is not to maximise yield per unit area but to optimise water productivity (benefit per unit water). Results of research experiments have shown substantial increases in crop yields and water productivity in response to the application of relatively small amounts of supplemental irrigation (Ghahraman and Spaskhah, 1997; Oweis et al., 1998, 2000; Fox and Rockström, 2003; Tavakoli and Oweis, 2004; Oweis and Hachum, 2006). At the farm level, supplemental irrigation increases yields, water productivity, and stability of crop production under different climatic conditions. These increases 
depend on site-specific environmental factors and management practices such as rainfall amount and distribution (especially at sowing date and heading-flowering stage), soil characteristics, crop cultivar, agronomic practices including fertiliser (amount, source, and timing), machinery, and control of weeds, pests, and disease.

The Karkheh River basin (KRB) in western Iran served as a benchmark basin for the Challenge Program on Water and Food of the Consultative Group on International Agricultural Research (CGIAR) and a number of hydrological assessments have been recently published (e.g. Muthuwatta et al., 2010; Masih et al., 2011). Most of the agricultural area in the upper KRB is rainfed. Annual precipitation in the upper catchments of the KRB ranges from 350 to $500 \mathrm{~mm}$ and yields of the dominant wheat crop are low. Iran's agricultural strategy identifies water productivity improvement as a top priority. Supplemental irrigation has been recommended as an important practice for increasing crop and water productivity in these rainfed areas of the upper KRB, which comprise important suitable rainfed zones of Iran (Keshavarz and Sadeghzadeh, 2000; Tavakoli et al., 2008, 2010).

The effects of supplemental irrigation on the yield of rainfed bread wheat (Triticum aestivum L.) was investigated under different scenarios in on-farm experiments conducted during the 2005-2008 cropping seasons at multiple farms in two benchmark watersheds in the upper KRB. The treatments included two main management strategies (traditional and advanced management) and four levels of irrigation: (i) rainfed, (ii) a single irrigation of about $50 \mathrm{~mm}$ at planting, (iii) a single irrigation of $75 \mathrm{~mm}$ in spring, and (iv) $50 \mathrm{~mm}$ at planting and $75 \mathrm{~mm}$ in spring. The results showed that a single irrigation application at sowing or spring time (during heading to flowering stage) increased total water productivity of wheat from 0.35 to an average of $0.57-0.63 \mathrm{~kg} \mathrm{~m}^{-3}$ over the three growing seasons. The average irrigation water productivity of wheat, which quantifies the yield increase (irrigated minus rainfed yield) due to irrigation, reached a range of $2.15-3.26 \mathrm{~kg} \mathrm{~m}^{-3}$. The application of the supplemental irrigation at critical stages, deep root expansion, increased green canopy cover, and its influence on evaporation control were main reasons for the effectiveness of supplemental irrigation. These results confirmed the potential of a single irrigation, either with early or normal planting, as an effective scheme to enhance productivity (Tavakoli et al., 2008, 2010).

A methodology that uses Geographic Information Systems (GIS) tools to identify potential areas for the introduction of supplemental irrigation has been developed by De Pauw et al. (2008). The method was based on the assumption that the irrigation water (from either surface or groundwater), used to fully irrigate summer crops in existing irrigated schemes, could instead be used in winter and spring for supplemental irrigation of winter crops. Since water requirements for supplemental irrigation are a fraction of that for full irrigation, the areas that could be irrigated in winter (wet and cold) are much larger than the areas currently used for full irriga- tion in summer (dry and hot). The method used a combination of a simple model to calculate the additional rainfed area that can be partially irrigated by the possible water savings, made by the shift from fully irrigated spring-summer crops to supplemental-irrigated winter-spring crops, with a water allocation procedure for the surrounding rainfed areas based on suitability criteria (De Pauw et al., 2008). A drawback of this method is that it implicitly assumes that current irrigation water withdrawals are sustainable, while its implementation would also require that farmers abandon or reduce summer cropping.

Allocation of limited water resources, environmental quality, and policies for sustainable water use are issues of increasing concern. The challenge is to determine the amount of water, and its quality, that should be allocated for the maintenance of the ecosystems through an "environmental flow allocation" and the water that can be allocated for agriculture, industry, and domestic services (Ramsar Convention Secretariat, 2007). Methods for estimating environmental flow requirements (EFRs) include hydrological methods, hydraulic rating, habitat simulation, and holistic methods (Mazvimavi et al., 2007). More than 30 criteria for single-river EFRs have been developed and used worldwide (Tennant, 1976; Hughes and Hannart, 2003; Mazvimavi et al., 2007; Ramsar Convention Secretariat, 2007; Smakhtin, 2001; Smakhtin et al., 2006). However, a lack of hydroecological studies often limits the choice of an EFR method. Tenant (1976) used detailed physical, chemical, and biological analyses at 50 stream cross sections in Nebraska, Montana and Wyoming to classify the streamflow conditions at different percentages of the average annual flow, ranging from 10 (poor) to $60-100 \%$ (optimum). They subsequently verified these results on hundreds of streams in 21 different states. In a global review, Tharme (2003) found that the Tenant method is the most commonly applied hydrology-based EFR method worldwide.

The objective of the present study is to develop a method for identifying potential areas for supplemental irrigation of rainfed cropland and to assess the consequences of supplemental irrigation on downstream flow under different flow conditions. The methodology was applied to the $43000 \mathrm{~km}^{2}$ upper KRB in Iran.

\section{Methods}

The analysis involved the following five steps: (1) processing of the digital elevation model (DEM), obtained from the $90 \mathrm{~m}$ resolution, Shuttle Radar Topography Mission (SRTM); (2) selection of a set of streamflow gages spanning the appropriate period of record and delineation of the watersheds of the selected gauges; (3) determination of the supplemental irrigation water needs and the EFRs for each subbasin; (4) identification of the areas suitable for supplemental irrigation; and (5) dynamic allocation of water to areas 
suitable for supplemental irrigation per sub-basin and downstream routing. Step 5 was repeated for four different flow scenarios and two irrigation options and provides the flow reduction to the Karkheh dam. Steps 2-5 are described in more detail below.

\subsection{Study area}

The KRB is located in southwest Iran, between $30^{\circ} 58^{\prime}-$ $34^{\circ} 56^{\prime} \mathrm{N}$ latitude and $46^{\circ} 06^{\prime}-49^{\circ} 10^{\prime} \mathrm{E}$ longitude. The area is about $50700 \mathrm{~km}^{2}$, with considerable variation in elevation, from a minimum of $3 \mathrm{~m}$ above sea level in the south (Dasht Azadeghan) to a maximum of $3645 \mathrm{~m}$ in the Karin Mountains in the north. The population of the area is around 4 million and is concentrated in the main cities and towns of Kermanshah, Khoramabad, Malayer, Songor, Kamyaran, Nahavand, and Sosangerd; otherwise ,the Karkheh River basin is rural. The area upstream of the Karkheh dam, referred to as upper KRB, covers $42908 \mathrm{~km}^{2}$. The main Karkheh River has a length of about $900 \mathrm{~km}$. The climate of the basin is semi-arid to arid. Most of the agricultural area in the upper KRB is rainfed and a large part of the region's agricultural livelihoods is based on dryland farming systems.

\subsection{Selection of flow gauging stations}

To cover both dry and wet periods, a 30-year period was used for the flow analysis. Flow gauge stations operating in KRB during the 1975-2004 period with at least 10-year data were selected, yielding a set of 53 stations. Key attributes available for each station record are latitude, longitude, starting year, and ending year. The 53 sub-basins were delineated with the help of the DEM. Mean monthly flows were computed for the 30-year period. Missing monthly data were filled in using linear regression relations and the normal ratio method (ASCE, 1996). A maximum coefficient of determination $\left(R^{2}\right)$, a statistically significant model ( $p$ value $=0.05)$, and availability of the corresponding data were the criteria for selecting suitable nearby stations from which to obtain the missing data. A map of upper KRB with the 53 watersheds is presented in Fig. 1.

\subsection{Water resource requirements}

Water requirements include existing needs (irrigation, industry, domestic), new supplemental irrigation requirements, and EFRs. At each gauge, station flows in excess of the domestic, industrial and irrigation uses are recorded. Thus, the recorded streamflow data assume all existing needs are satisfied.

The supplemental irrigation requirements were taken from a field study on wheat undertaken in two sub-basins in KRB (Tavakoli et al., 2008, 2010), but with consideration of conveyance efficiency, assumed to be approximately $75 \%$ for earthen channels between the stream and the field (Brouwer et al., 1989). The following strategies were considered: (i) a single irrigation of $100 \mathrm{~mm}$ in autumn; (ii) two irrigations of $75 \mathrm{~mm}$ each in the spring. Wheat is planted in October and harvested in early July. These would result in field applications of $75 \mathrm{~mm}$ (fall) and $112 \mathrm{~mm}$ (spring). Autumn irrigations are applied in October and spring irrigations in May. Temperatures in the three lowest sub-basins before the dam (22, 33, and 39) are higher than those in the remainder of the basin, and here crops are planted later and harvested earlier. In these basins irrigations are applied in November and April. These irrigation strategies represent recommendations that can be implemented by local farmers and that provide policy makers with clear scenarios for improving yield of rainfed wheat with supplemental irrigation in upper KRB. The monthly irrigation water requirements for each sub-basin are calculated based on the mapped suitable areas, as explained below.

Because of the lack of biological data for the basin, the hydrology-based Tenant (Montana) method was applied for the EFR. Tenant (1976) stressed that $10 \%$ is the lower limit for the well-being of many aquatic organisms. Considering the general water scarcity in the area, $15 \%$ of the mean annual runoff (MAR) of each sub-basin was used as an EFR. By subtracting the EFRs from the monthly flow data, the available water for allocation to supplemental irrigation areas of all sub-basins could be determined. All monthly flows were based on the observed 30-year average flows at the 53 subbasin outlets.

\subsection{Areas suitable for supplemental irrigation}

To assess the maximum possible area of land for supplemental irrigation, all rainfed crop areas with less than $20 \%$ slope were considered. The rainfed crop areas were taken from the land use/land cover map of Iran (FRWO, 1998). The map was overlayed with the slope map derived from the DEM, to identify four different slope classes: $0-5,5-8,8-12$, and $12-$ $20 \%$. These slope classes determine the suitability of land for different types of irrigation and could be used to set different priorities for irrigation expansion. The slopes used for different irrigation methods are surface (less than $5 \%$ ), sprinkler $(0-8 \%)$, and trickle (0-12\%). Ideally, slopes above $12 \%$ should neither be cultivated with field crops nor irrigated, because it leaves the land vulnerable to erosion.

River surface flow was assumed to be the sole source of water for irrigation. Potential rainfed areas for supplemental irrigation were considered within buffers of $1000 \mathrm{~m}$ around the streams. This buffer is based on expert knowledge of the maximum distance considered feasible for conveying water away from the water source without large investments in infrastructure or pumping. To determine areas suitable for supplemental irrigation in each sub-basin, the stream buffer area map is overlayed on that of the rainfed slope classes of the 53 subbasins, from which the so-called iso-potential map for supplemental irrigation is derived (Fig. 1). 


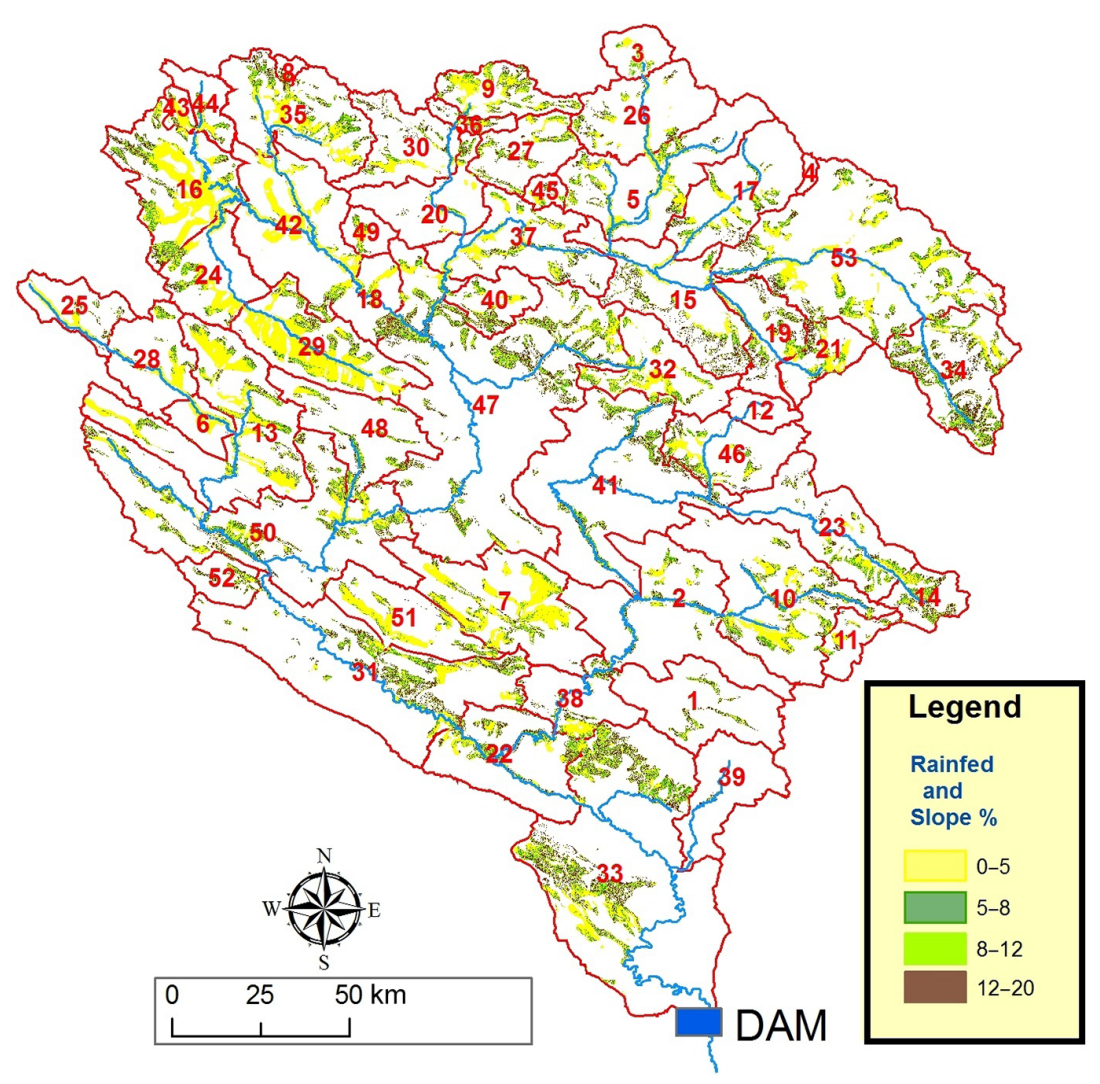

Figure 1. Gauged sub-basins and rainfed areas suitable for supplemental irrigation in upper Karkheh River basin for four different slope classes.

\subsection{Water allocation}

A Fortran program was developed to dynamically allocate the streamflow to the areas suitable for supplemental irrigation. The routing scheme identifies for each sub-basin the number of upstream basins and the downstream basin. To ensure that sufficient water remains for all current water allocations, first the available streamflow in each sub-basin is computed. Starting from downstream, the available flow of each sub-basin is computed by subtracting the inflow of upstream basins from the outflow of the sub-basin. If the outflow from a sub-basin is less than the sum of the inflows, it means that the water use in the sub-basin exceeds the local water resources. Thus, part of the flow coming from upstream has been allocated in the sub-basin. This flow deficit is distributed among its inflowing upstream sub-basins, relative to their flow. Thus the available flow of upstream sub-basins is the outflow minus the inflows and minus an equitable share of any deficit of the downstream sub-basin. After the available water resources for each sub-basin have been computed, the water is allocated for supplemental irrigation. Starting from the upstream sub-basins, the available water is allocated to the supplemental irrigation areas, and any remaining water is routed downstream.
Four different flow scenarios were applied: (i) the 30-year mean flow, referred to as normal; (ii) normal with EFRs; (iii) drought flow conditions; (iv) drought conditions with EFRs. The drought flows of the sub-basins were defined as the flows with an $80 \%$ probability of exceedance. For each flow scenario, four slope classes were used: $0-5,0-8,0$ 12 , and $0-20 \%$. Finally, two irrigation options were simulated: (i) supplemental irrigation in both spring and autumn and (ii) supplemental irrigation in either autumn or spring or both, depending on water availability. The first option is more restrictive, because it would consider irrigating only the areas that have sufficient streamflow in both seasons. Thus, the program is used to compute actual supplemental irrigation areas in upper KRB sub-basins for different land suitability classes, flow scenarios, and irrigation development options.

By applying the computer program, actual areas suitable for the development of supplemental irrigation and the flows that can be allocated for irrigation are calculated along the river. The impacts of the scenarios on streamflow are evaluated for each sub-basin and, subsequently, for the whole basin. Finally, the effect of the four scenarios on the outflow to the Karkheh dam is compared. 


\section{Results and discussion}

The rainfed crop areas cover $15840 \mathrm{~km}^{2}$ of the total 42908 $\mathrm{km}^{2}$ area of upper KRB. More than one-third (37\%) of the rainfed crop land has slopes up to $5 \%$, while $50 \%$ of the rainfed areas have slopes up to $8 \%$. The higher slope classes cover $13 \%$ (8-12\% slope) and $16 \%$ (12-20\% slope) of the rainfed areas, whereas $21 \%$ are not suitable for cultivation.

In all, $61 \%\left(3559 \mathrm{~km}^{2}\right)$ of the rainfed crop areas with slopes up to $5 \%$ are suitable for supplemental irrigation due to their location within $1000 \mathrm{~m}$ buffer distance of the streams. This is $22 \%$ of the total rainfed crop area. If all rainfed croplands with slopes up to $20 \%$ are considered, $46 \%\left(7361 \mathrm{~km}^{2}\right)$ of the total rainfed crop area is suitable for supplemental irrigation. The location of these areas is shown in Fig. 1. These numbers are in the same range as those of Masih et al. (2011), who used the Soil Water Assessment Tool (SWAT) to allocate irrigation water from streams to rainfed wheat and found that $33 \%\left(4680 \mathrm{~km}^{2}\right)$ of the $14020 \mathrm{~km}^{2}$ rainfed crop area in upper KRB could be potentially converted to irrigated agriculture.

Figure 2 presents the upper Karkheh River basin rainfed crop areas for the four slope classes $(0-5,0-8,0-12$, and 0 $20 \%$ ), the areas suitable for supplemental irrigation (within $1 \mathrm{~km}$ buffer from the streams) and the suitable areas that could receive supplemental irrigation under the four flow scenarios. The figure clearly shows that the streamflow is sufficient to irrigate only a fraction of the suitable rainfed areas within $1 \mathrm{~km}$ from the streams. For application of irrigation in both autumn and spring (Fig. 2a) under normal flow, 36\% $\left(1278 \mathrm{~km}^{2}\right)$ of the suitable rainfed land on $0-5 \%$ slopes can be irrigated or $28 \%\left(2057 \mathrm{~km}^{2}\right)$ of the suitable rainfed land on $0-20 \%$ slopes.

The 30-year mean flows (normal) at the Karkheh dam are the lowest between August and October $\left(54-57 \mathrm{~m}^{3} \mathrm{~s}^{-1}\right)$ and the highest in March $\left(363 \mathrm{~m}^{3} \mathrm{~s}^{-1}\right)$, April $\left(421 \mathrm{~m}^{3} \mathrm{~s}^{-1}\right)$, and May $\left(284 \mathrm{~m}^{3} \mathrm{~s}^{-1}\right)$. Due to of the scarcity of water in autumn, the more restrictive irrigation option, which requires water for both autumn and spring irrigation (Fig. 2a), covers about half of the area that will be irrigated under the less restrictive option, which applies either autumn or spring irrigation (Fig. 2b). Under drought conditions, outflows to the dam average $42 \mathrm{~m}^{3} \mathrm{~s}^{-1}$ in October and $126 \mathrm{~m}^{3} \mathrm{~s}^{-1}$ in May. But there is little water in the upstream areas of upper KRB, which are most suitable for supplemental irrigation, and the difference between the two irrigation options remains small.

Figure 3 shows the average annual streamflow to Karkheh dam before and after the application of supplemental irrigation, for the four flow scenarios, four slope classes and two irrigation options. Note that without supplemental irrigation the outflows with and without EFRs remain the same. For irrigation in autumn and spring (Fig. 3a) and normal flow conditions, the average annual flow $\left(177 \mathrm{~m}^{3} \mathrm{~s}^{-1}\right)$ is reduced by $9 \%$, if all slope classes (0-20\%) are irrigated. The largest reduction of flows is in October. The outflow to the dam is re-
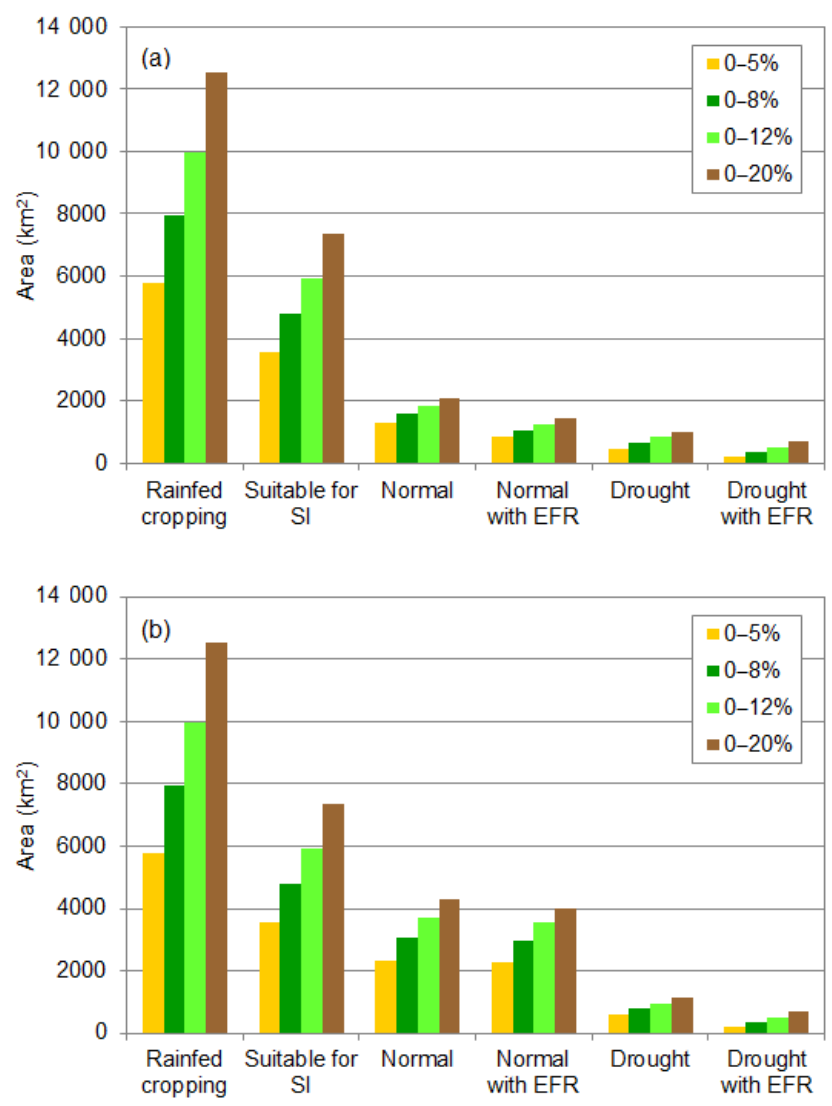

Figure 2. Rainfed crop areas for four different slope classes for the whole upper Karkheh River basin; rainfed crop areas suitable for supplemental irrigation (SI) (within $1 \mathrm{~km}$ buffer from the streams); and suitable areas that receive supplemental irrigation under the four flow scenarios (normal flow, normal with environmental flow requirements (EFRs), drought conditions, and drought with EFRs); areas that receive both autumn and spring irrigation (a); areas that receive either autumn or spring irrigation or both (b).

duced from 57 to $17 \mathrm{~m}^{3} \mathrm{~s}^{-1}$ for the $0-5 \%$ slopes to $6 \mathrm{~m}^{3} \mathrm{~s}^{-1}$ for the $0-20 \%$ slopes. The impacts are much less significant in November, April, and May. Outflows for irrigation of the $0-20 \%$ slopes are 88,380 , and $208 \mathrm{~m}^{3} \mathrm{~s}^{-1}$, respectively, and reductions range between 10 and $27 \%$.

If EFRs are considered the annual flow reduction becomes $6 \%$. The outflows of the basin in October are 33 and $29 \mathrm{~m}^{3} \mathrm{~s}^{-1}$ for the $0-5 \%$ and $0-20 \%$ areas, respectively. The results indicated that the EFRs of $15 \%$ of the mean annual flow throughout the basin may be a suitable criterion for reducing environmental impact of irrigation water withdrawal. Under drought conditions the average annual flow to the dam is $90 \mathrm{~m}^{3} \mathrm{~s}^{-1}$ and the relative flow reductions are similar. However, the irrigation is constrained by the water availability in the basin and the reductions in outflows are less than under normal flow conditions. Outflows to the dam for the irrigation of $0-20 \%$ slopes in October is reduced from 42 to $30 \mathrm{~m}^{3} \mathrm{~s}^{-1}$ and from 67 to $41 \mathrm{~m}^{3} \mathrm{~s}^{-1}$ in November. 

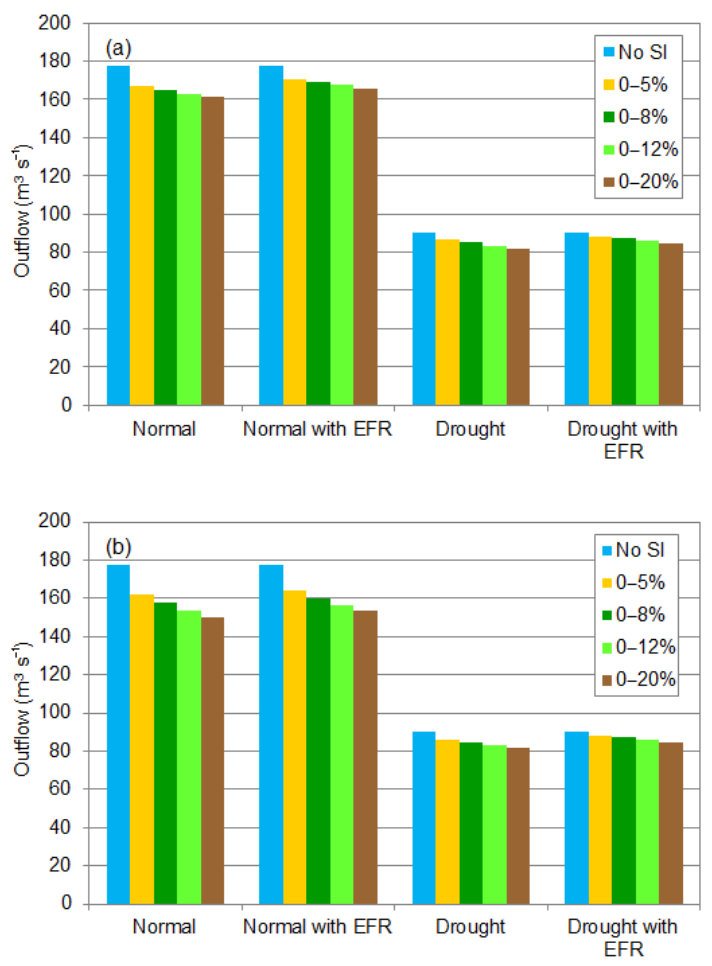

Figure 3. Average annual outflow to Karkheh dam, before and after supplemental irrigation (SI) withdrawal for four slope classes and four flow scenarios (normal flow, normal with environmental flow requirements (EFRs), drought conditions, and drought with environmental flow); areas that receive both autumn and spring irrigation (a); areas that receive either autumn or spring irrigation or both (b).

For the less restrictive irrigation option (Fig. 3b), the reductions of downstream flows for the irrigation of all slope classes were $15 \%$ for normal flow, $13 \%$ for normal flow with EFRs, $9 \%$ for drought conditions, and $6 \%$ for drought conditions with EFRs. Similar results were found by Masih et al. (2011), who found a reduction of $10 \%$ in the average annual streamflow of upper KRB.

The results of the analysis indicate that implementation of supplemental irrigation in the rainfed areas will not reduce the average annual flow to the Karkheh reservoir significantly. Furthermore, the reservoir storage will also reduce the impact of the seasonal withdrawals. At the same time, supplemental irrigation is expected to provide considerable benefits for yield and water productivity in the upper KRB.

Figure 4 shows the supplemental irrigation areas of the 53 sub-basins for the four flow scenarios and three slope classes. These figures clearly show that in the upstream sub-basins water is the limiting factor, whereas in the downstream areas good quality land is a limiting factor. Under the two normal flow scenarios, in the upstream sub-basins, all available water is used to irrigate rainfed lands with slopes less than $5 \%$. But for the downstream sub-basins, the irrigated area keeps on increasing if we move from the first slope class $(0-5 \%)$ to the third $(0-12 \%)$ and fourth slope class $(0-20 \%)$.

The maps for the drought scenarios also provide an important message. In drought years, when the rainfed crops will be water-stressed, no streamflow is available for supplemental irrigation in the upstream sub-basins. However, even under the drought scenario a total of $2.7 \times 10^{9} \mathrm{~m}^{3} \mathrm{yr}^{-1}$ will flow to the dam. Thus, to irrigate a larger share of the rainfed areas, water need to be stored in the upstream areas in small and medium sized dams. Options for artificial recharge of groundwater with streamflows through check dams in the river bed or with off-stream basins could also be investigated (e.g. Khan et al., 2008). Water could be captured during the wet winter and early spring months for subsequent use later in spring.

\section{Conclusions}

A methodology was developed that allows for the allocation of irrigation water and the mapping of areas that are suitable for supplemental irrigation at the basin level, based on a land use map, DEM and long-term flow records at different sub-basins. The computations of the flows before and after applying supplemental irrigation strategies allowed evaluating: (i) the impacts of different supplemental irrigation strategies on streamflow, (ii) assessment of the water demand at each sub-basin, (iii) the spatial water allocation pattern, and (iv) the available and allocated water for each strategy. The application of these methods to upper KRB in Iran revealed that implementation of supplemental irrigation in the rainfed areas of the upper basin does not substantially reduce the average annual flow to the Karkheh reservoir, while it is expected to provide considerable yield and water productivity benefits.

Under normal flow conditions (30-year average) a maximum of $2057 \mathrm{~km}^{2}$, which represents $13 \%$ of the rainfed crop areas and $28 \%$ of the area suitable for supplemental irrigation, could be provided with supplemental irrigation in autumn and spring. This would reduce the streamflow by $9 \%$. If EFRs are considered, this area would be reduced to $1444 \mathrm{~km}^{2}$, while under drought conditions a maximum of $1013 \mathrm{~km}^{2}$ could be provided with supplemental irrigation. The analysis clearly showed that the upstream subbasins are water limited, while the lower sub-basins are limited with regards to suitable rainfed cropland. The methodology, the criteria, and the scenarios may be refined further by including socioeconomic factors. In particular, the predicted changes in farm incomes under the proposed options may help influence policies for the reallocation of available water resources. Economic studies could also consider additional scenarios such as hydropower and irrigation downstream of the dam. Furthermore, ecological studies could be done to base the EFRs on biological indicators, which could be integrated in hydrologic models that represent surface and groundwater processes. 

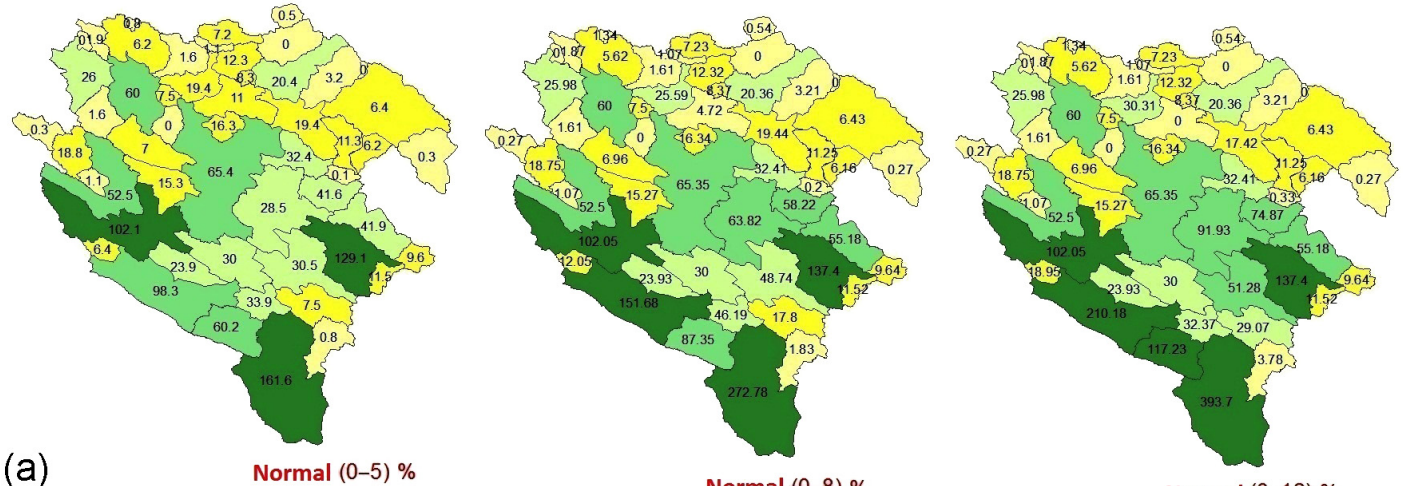

Normal (0-8) \%

Normal $(0-12) \%$
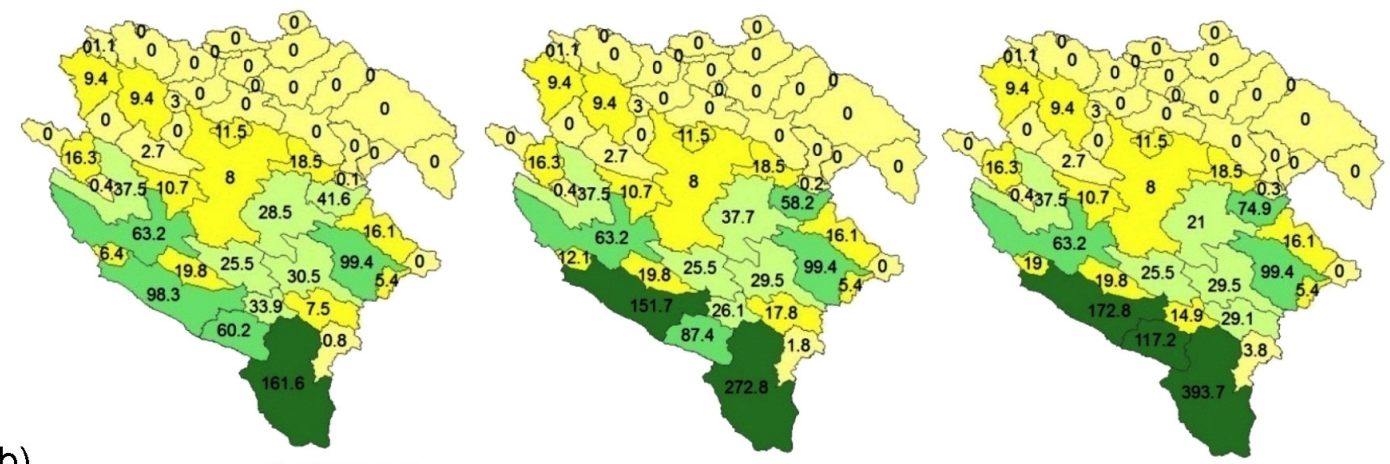

(b)

N - EFR (0-5) \%

N - EFR (0-8) \%

N - EFR (0-12) \%
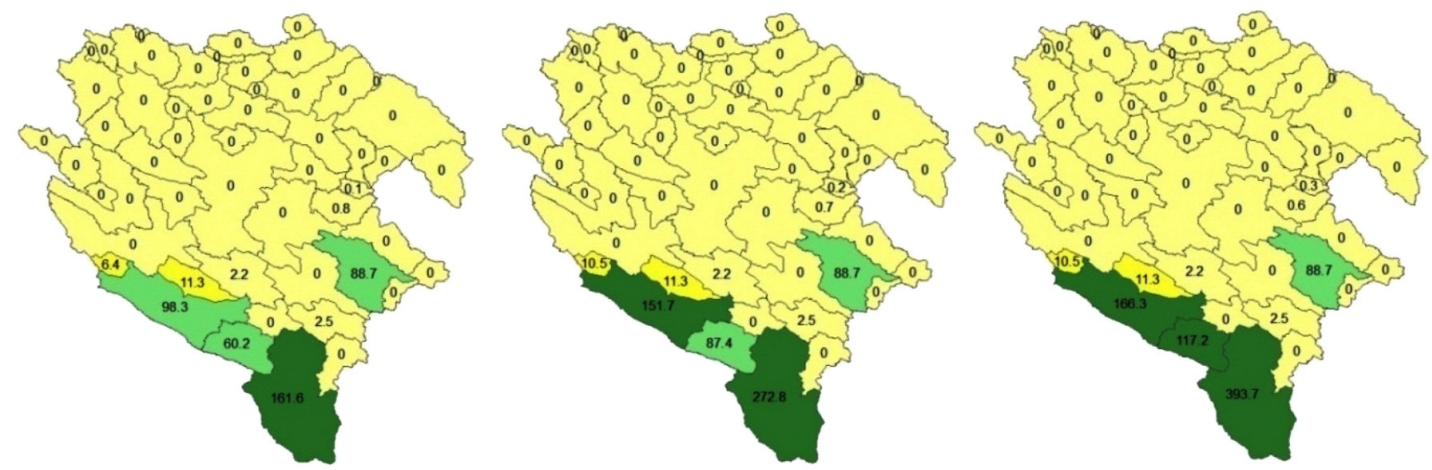

(c)

Drought (0-5) \%

Drought (0-8) \%

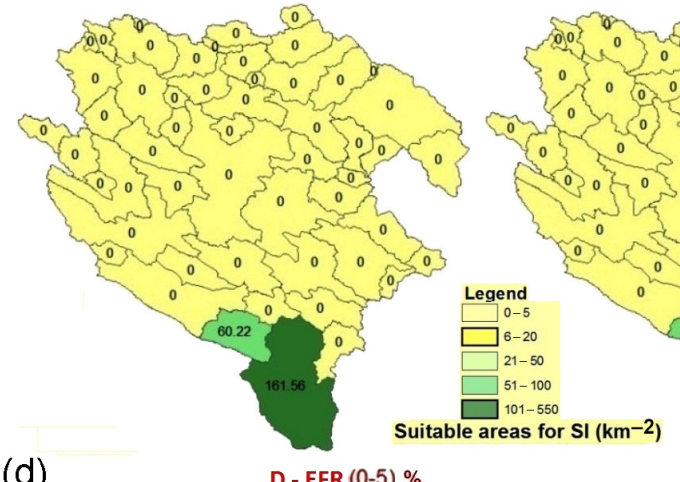

Drought $(0-12) \%$

(d)

D - EFR (0-5) \%
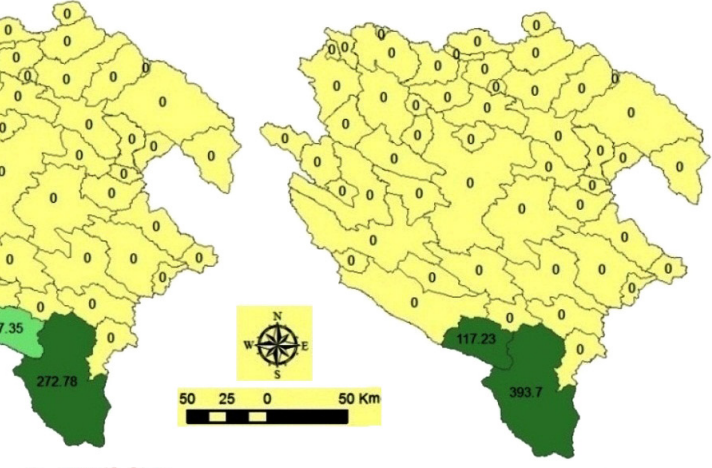

$D-\operatorname{EFR}(0-8) \%$

D - $\operatorname{EFR}(0-12) \%$

Figure 4. Areas that could receive supplemental irrigation in autumn and spring in the 53 sub-basins of Karkheh River basin, for three slope classes and four flow scenarios (normal flow, normal with environmental flow requirements (EFRs), drought conditions, and drought with EFRs). 
Acknowledgements. This paper presents findings from CP-WF PN08 "Improving On-farm Agricultural Water Productivity in the Karkheh River Basin", a project of the CGIAR Challenge Program on Water and Food. The authors would like to thank the following institutions for their support: CGIAR Challenge Program on Water and Food; Agricultural Research, Extension, and Education Organization (AREEO), Ministry of Jihad -e- Agriculture, Iran; International Center for Agricultural Research in the Dry Areas (ICARDA), Aleppo, Syria; and Agricultural Engineering Research Institute, (AERI), Karaj. We also gratefully acknowledge the contribution of Ahmed Y. Hachum for his help in reviewing this paper. We would like to thank the two anonymous reviewers for their suggestions and comments.

Edited by: S. Uhlenbrook

\section{References}

ASCE (American Society of Civil Engineers): Hydrology handbook, 2nd Edn., ASCE Manuals and reports on engineering practice, No 28, ASCE, Danvers, MA, 1996.

Brouwer, C., Prins, K., and Heibloem, M.: Irrigation water management: Irrigation scheduling, Training manual 4, FAO, Rome, 1989.

De Pauw, E., Oweis, T., Nseir, B., and Youssef, J.: Spatial modelling of the biophysical potential for supplemental irrigation: methodology and a case study in Syria, ICARDA, Aleppo Syria, 2008.

Fox, P. and Rockström, M. J.: Supplemental irrigation for dry-spell mitigation of rainfed agriculture in the Sahel, Agr. Water Manage., 61, 29-50, 2003.

FRWO (Forest and Ranges and Watershed Organization): Land cover/land use of Iran extracted from Landsat Images of 1998, FRWO Engineering \& Technical Bureau, 1998 (in Persian).

Ghahraman, B. and Sepaskhah, A. R.: Use of a water deficit sensitivity index for partial irrigation scheduling of wheat and barley, Irrigation Sci., 18, 11-16, 1997.

Hughes, D. A. and Hannart, P.: A desktop model used to provide an initial estimate of ecological instream flow requirements of rivers in South Africa, J. Hydrol., 270, 167-181, 2003.

Keshavarz, A. and Sadeghzadeh, K.: Agricultural water management: current situation, future perspective and some strategies for its optimization, in: Proceedings of the 10th Seminar of Iranian National Committee on Irrigation and Drainage, 15-16 November 2000, Tehran, Iran, IRNCID Publication No. 38, 2000 (in Persian).

Khan, S., Mushtaq, S., Hanjra, M. A., and Schaeffer, J.: Estimating potential costs and gains from an aquifer storage and recovery program in Australia, Agr. Water Manage., 95, 477-488, 2008.
Masih, I., Maskey, S., Uhlenbrook, S., Smakhtin, V.: Impact of upstream changes in rain-fed agriculture on downstream flow in a semi-arid basin, Agric. Water Manage., 100, 36-45, 2011.

Mazvimavi, D., Madamombe, E., and Makurira, H.: Assessment of environmental flow requirements for river basin planning in Zimbabwe, Phys. Chem. Earth, 32, 995-1006, 2007.

Muthuwatta, L. P., Ahmad, M. D., Bos, M. G., and Rientjes, T. H. M.: Assessment of water availability and consumption in the Karkheh River Basin, Iran - using remote sensing and geostatistics, Water Resour. Manage., 24, 459-484, 2010.

Oweis, T. and Hachum, A.: Water harvesting and supplemental irrigation for improved water productivity of dry farming systems in West Asia and North Africa, Agr. Water Manage., 80, 57-73, 2006.

Oweis, T., Pala, M., and Ryan, J.: Stabilizing rainfed wheat yields with supplemental irrigation and nitrogen in a Mediterraneantype climate, Agron. J., 90, 672-681, 1998.

Oweis, T., Zhang, H., and Pala, M.: Water use efficiency of rainfed and irrigated bread wheat in a Mediterranean environment, Agron. J., 92, 231-238, 2000.

Ramsar Convention Secretariat: Water allocation and management: Guidelines for the allocation and management of water for maintaining the ecological functions of wetlands, Ramsar handbooks for the wise use of wetlands, 3rd Edn., Ramsar Convention Secretariat, Gland, Switzerland, 8, 64 pp., 2007.

Smakhtin, V. U.: Low flow hydrology: a review, J. Hydrol., 240, 147-186, 2001.

Smakhtin, V. U., Shilpakar, R. L., and Hughes, D. A.: Hydrologybased assessment of environmental flows: an example from Nepal, Hydrological Sciences Journal, 47, 207-222, 2006.

Tavakoli, A. R. and Oweis, T.: The role of supplemental irrigation and nitrogen in producing bread wheat in the highlands of Iran, Agr. Water Manage., 65, 225-236, 2004.

Tavakoli, A. R., Liaghat, A., Alizadeh, A., Ashrafi, Sh., Oweis, T., Parsinejad, M.: On-farm rain water productivity improvement in producing rainfed wheat by advanced scenarios at semi-cold region of upper Karkheh River Basin (KRB), Iranian Journal of Irrigation and Drainage, 4, 297-307, 2010.

Tavakoli, A. R., Oweis, T., Ashrafi, Sh., Liaghat, A., Abbasi, F., AND Farahani, H.: Role of transfer of new technologies to improve water productivity of major rainfed crops in Karkeh River Basin, in: Proceedings of an International Workshop on Improving Water Productivity and Livelihood Resilience in the Karkeh River Basin in Iran, 10-11 September 2007, ICARDA, Aleppo, Syria, 5-16, 2008.

Tennant, D. L.: Instream flow regimens for fish, wildlife, recreation and related environmental resources, Fisheries, 1, 6-10, 1976.

Tharme, R. E.: A global perspective on environmental flow assessment: emerging trends in the development and application of environmental flow methodologies for rivers, River Res. Appl., 19, 397-441, 2003. 